\title{
Short communication: Milk fat payment affects the relative profitability of Jersey and Holstein-Friesian cows at optimal comparative stocking rate
}

\author{
J. P. Edwards, ${ }^{1 *}$ O. K. Spaans, ${ }^{2}$ M. Neal, ${ }^{2}$ and K. A. Macdonald ${ }^{2}$ \\ ${ }^{1}$ DairyNZ, Lincoln 7647, New Zealand \\ ${ }^{2}$ DairyNZ, Hamilton 3240, New Zealand
}

\begin{abstract}
Choice of stocking rate and breed of cow are 2 strategic decisions that affect the profitability of pasturebased dairy farm businesses. This study sought to analyze the effects of a range of fat and protein prices on the profitability of the Jersey $(\mathrm{J})$ and Holstein-Friesian (HF) breeds at 2 comparative stocking rates (CSR): $80 \mathrm{~kg}$ of body weight (BW) per tonne of dry matter (DM) of feed (CSR80), and $100 \mathrm{~kg}$ of BW per tonne of DM of feed (CSR100). Data were obtained from a recently published study, and equations constructed to determine the values for fat and protein at which each breed broke even (profit $=\mathrm{NZ} \$ 0 /$ ha; at time of writing, $\mathrm{NZ} \$ 1=\mathrm{US} \$ 0.69$ or $€ 0.60)$, returned equal profit, and exceeded the other breed by $1 \%$ or $5 \%$. At CSR100 there were few combinations of fat and protein prices for which HF were more profitable than J. At CSR80, J and HF were equally profitable at a fat price of NZ $\$ 5.67 \pm \mathrm{NZ} \$ 0.20$ per kilogram, depending on protein price. The study also highlighted the importance of including volume adjustments in milk price calculations when differences in milk composition exist, as the fat price at which the profitability of $\mathrm{HF}$ and $\mathrm{J}$ were equal was $\mathrm{NZ} \$ 1.23 / \mathrm{kg}$ lower when volume adjustments were included. The recent increase in the value of fat relative to protein favors J. Farmers should consider the medium- to long-term outlook of fat price when evaluating breed choice for their farm system.
\end{abstract}

Key words: breed, Jersey, Holstein-Friesian, profit

\section{Short Communication}

In pasture-based dairy farm systems, choice of stocking rate $(\mathbf{S R})$ and breed of cow are strategic decisions that will affect the production efficiency and profitability of a farm business (Spaans et al., 2018). Two

Received December 12, 2018.

Accepted June 3, 2019.

*Corresponding author: Paul.Edwards@dairynz.co.nz common pure breeds in pastoral dairy farms are Jersey $(\mathbf{J})$ and Holstein-Friesian (HF; ICBF, 2017a; DairyNZ, 2018a). Several studies have reported that J cows have superior production efficiency (kilograms of milk solids per kilogram of feed) compared with HF cows in a restricted intake environment (L'Huillier et al., 1988; Prendiville et al., 2009; Beecher et al., 2014). However, 50 to $60 \%$ of costs in a grazing system are incurred by individual cows rather than by pasture and facilities (Macdonald et al., 2011); therefore, the greater efficiency of the $\mathrm{J}$ breed may be offset by the need to carry more animals per hectare to achieve a similar level of production per hectare to that of the HF breed.

A recently published study analyzed the effects of interactions between breed and SR in a multi-year farmlet study on production and profitability (Spaans et al., 2018). The study was conducted between 1990 and 1993. All combinations of 2 breeds ( $\mathrm{HF}$ and J) and 2 comparative stocking rates (CSR), $80 \mathrm{~kg}$ of BW per tonne of DM of feed (CSR80) and $100 \mathrm{~kg}$ of BW per tonne of DM of feed (CSR100) were compared. Actual stocking rates were 3.0 and 3.6 cows per hectare (22 and 26 cows) at CSR80 and 4.0 and 4.5 cows per hectare (29 and 33 cows) at CSR100 for HF and J cows, respectively. The CSR80 treatment was chosen as the optimum stocking rate for farm profitability (Macdonald et al., 2011), and CSR100 was chosen to test the hypothesis that the $\mathrm{J}$ breed would be more efficient converters of feed, and therefore more profitable, in a restricted intake environment. Interactions between breed and CSR were found for a range of variables measured (Spaans et al., 2018). Jerseys produced more fat and protein per hectare at both stocking rates; however, due to a greater proportion of fat, the economic value of each kilogram of milk was less, by NZ\$0.09/ $\mathrm{kg}$ at CSR 80 and by NZ $\$ 0.11 / \mathrm{kg}$ at CSR100 (Spaans et al., 2018). This, combined with differences in operating expenses, resulted in $\mathrm{J}$ cows being more profitable at CSR100 but less profitable at CSR 80 when compared with HF. The CSR 80 treatments were more profitable than CSR100 for both breeds, consistent with the findings of Macdonald et al. (2011). 
A recent increase in global demand for milk fat has resulted in a significant increase in its value relative to protein (Global Dairy Trade, 2017). This may change the relative profitability of the 2 breeds (Schmidt and Pritchard, 1988; Elbehri et al., 1994; Bailey et al., 2005). The objective of this study was to analyze the effects of a range of fat and protein prices on the profitability of $\mathrm{J}$ and HF at CSR80 and CSR100 and to determine at what fat and protein prices $\mathrm{J}$ would be more profitable than HF.

Data required were obtained from Spaans et al. (2018) and included kilograms of fat and kilograms of protein produced per hectare, other income per hectare (e.g., sale of cull cows and calves), and operating expenses per hectare. Relevant variables are reproduced in Table 1. Since the time the Spaans et al. (2018) study was conducted, genetic selection has affected both $\mathrm{J}$ and HF cows, with an increase in both the live weight and fat and protein production per cow (DairyNZ, 2018a). However, national averages of fat and protein production per hectare in 2017 to 2018 were similar to those reported in the study by Spaans and colleagues. Spaans et al. (2018) calculated the economics of each treatment (Table 1) using physical data collected from each farmlet (average of 3 seasons) and the average expenses of system 1 and 2 farms (farms that use no imported feed or that use imported feed for nonlactating cows; DairyNZ, 2018b) extracted from DairyBase, a financial and herd management benchmarking tool (DairyNZ, 2017) for the seasons 2012/13, 2013/14, and 2014/15. Each expense category was classed as a per-hectare or per-cow expense, or a combination of both, using the proportions published by Macdonald et al. (2011).

Profit per hectare was defined in Equation [1]:

Profit $(\$ / h a)=(F \$ \times F k g)+(P \$ \times P k g)+$ OthInc - OpEx,

where $\mathrm{F} \$$ was the value of fat $(\mathrm{NZ} \$ / \mathrm{kg})$, Fkg was kilograms of fat produced per hectare, $\mathrm{P} \$$ was the value of protein $(\mathrm{NZ} \$ / \mathrm{kg}), \quad \mathrm{Pkg}$ was kilograms of protein produced per hectare, OthInc was the value of other income (NZ\$/ha), and OpEx was the operating expenditure $(\mathrm{NZ} \$ /$ ha). At the time of writing, $\mathrm{NZ} \$ 1=$ US $\$ 0.69$ or $€ 0.60$.

Relative profitability between breeds was defined in Equation [2]:

$$
\mathrm{X}(\%)=\frac{\text { Profit }_{\mathrm{B} 1}-\text { Profit }_{\mathrm{B} 2}}{\text { Profit }_{\mathrm{B} 2}},
$$

where Profit ${ }_{\mathrm{B} 1}$ was the profit per hectare of breed 1 , Profit $_{\mathrm{B} 2}$ was the profit per hectare of breed 2, and $\mathrm{X}$ was the percent advantage in profit per hectare that breed 1 had over breed 2 .

A seasonal volume adjustment was applied, using Equation [3], to account for differences in fat and protein percentages between the breeds. The adjustment applied was a penalty if lower than the average fat and protein composition (e.g., HF), or a credit if higher than the average composition (e.g., J) and was added

Table 1. Key farm system metrics, derived from Spaans et al. (2018), required to calculate operating profit per hectare at a range of fat and protein prices (NZ $\$$; at time of writing, NZ\$1 = US\$0.69 or $€ 0.60)$

\begin{tabular}{|c|c|c|c|c|}
\hline \multirow[b]{2}{*}{ Item } & \multicolumn{2}{|c|}{$\mathrm{CSR} 80^{1}$} & \multicolumn{2}{|c|}{ CSR $100^{2}$} \\
\hline & $\mathrm{J}^{3}$ & $\mathrm{HF}^{4}$ & $\mathrm{~J}$ & $\mathrm{HF}$ \\
\hline Milk yield (kg/ha) & 11,510 & 13,816 & 12,111 & 13,346 \\
\hline Fat yield $(\mathrm{kg} / \mathrm{ha})$ & 708 & 638 & 740 & 609 \\
\hline Protein yield (kg/ha) & 484 & 486 & 491 & 456 \\
\hline Fat percentage & 6.2 & 4.6 & 6.1 & 4.6 \\
\hline Protein percentage & 4.2 & 3.5 & 4.1 & 3.4 \\
\hline Other income (NZ\$/ha) & 513 & 506 & 566 & 658 \\
\hline Labor expenses & 1,314 & 1,122 & 1,602 & 1,442 \\
\hline Stock expenses & 725 & 621 & 888 & 802 \\
\hline Feed expenses & 315 & 249 & 394 & 361 \\
\hline Other working expenses & 1,151 & 1,081 & 1,256 & 1,197 \\
\hline Overheads & 682 & 637 & 751 & 713 \\
\hline Operating expenses (NZ\$/ha) & 4,186 & 3,710 & 4,891 & 4,515 \\
\hline
\end{tabular}

${ }^{1}$ Comparative stocking rate of $80 \mathrm{~kg}$ of $\mathrm{BW}$ per tonne of DM of feed.

${ }^{2}$ Comparative stocking rate of $100 \mathrm{~kg}$ of $\mathrm{BW}$ per tonne of $\mathrm{DM}$ of feed.

${ }^{3} \mathrm{~J}=$ Jersey.

${ }^{4} \mathrm{HF}=$ Holstein-Friesian. 
as an additional operating expense to that reported in Table 1. Equation [3] is as follows:

$$
\begin{aligned}
& \text { Vol adjust }(\mathrm{NZ} \$ / \mathrm{ha})= \\
& \frac{\left(\text { Fat }_{\mathrm{B}}+\text { Protein }_{\mathrm{B}}\right)-\left(\text { Fat }_{\mathrm{Avg}}+\text { Protein } \%_{\mathrm{Avg}}\right)}{\left(\text { Fat }_{\mathrm{Avg}}+\text { Protein }_{\mathrm{Avg}}\right)} \\
& \times 0.0292 \times\left(\text { Milk }_{\mathrm{B}} / 1.03\right),
\end{aligned}
$$

where the subscript $\mathrm{B}$ refers to breed ( $\mathrm{J}$ or HF), subscript Avg refers to the average fat or protein percentage of $\mathrm{J}$ and HF, NZ $\$ 0.0292 / \mathrm{L}$ was the average seasonal volume adjustment between 2011/12 and 2017/18 applied by a large milk processor (Figure 1; Fonterra Co-operative Group, Auckland, New Zealand), Milk was the milk produced $(\mathrm{kg} / \mathrm{ha})$ by the breed, and 1.03 $\mathrm{kg} / \mathrm{L}$ was the density of milk. This equated to an adjustment of $+\mathrm{NZ} \$ 39 /$ ha for $\mathrm{J}$ and $-\mathrm{NZ} \$ 47 /$ ha for $\mathrm{HF}$ at CSR80, and $+\mathrm{NZ} \$ 41 /$ ha for $\mathrm{J}$ and $-\mathrm{NZ} \$ 45 /$ ha for $\mathrm{HF}$ at CSR100. In block calving systems, processors may apply additional adjustments for peak production months (Sep. 1 to Dec. 31 in the southern hemisphere), using the same formula as the seasonal volume adjustment, to account for capital costs required to process peak milk. These adjustments were not applied in the present analysis. Inclusion of a peak volume adjustment would favor the $\mathrm{J}$ breed.

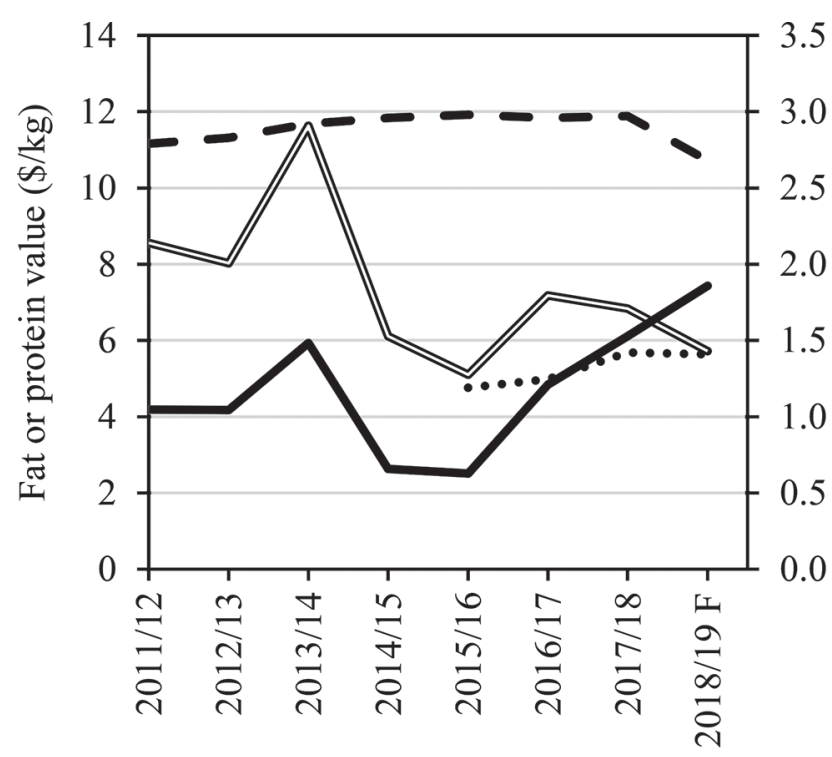

Production season

Figure 1. Actual values (NZ\$) of fat (solid line), protein (double line), seasonal volume adjustment (dashed line), and peak volume adjustment (dotted line) paid by a large milk processor (Fonterra Cooperative Group, Auckland, New Zealand). Not adjusted for inflation. $\mathrm{F}=$ forecast. At time of writing, $\mathrm{NZ} \$ 1=\mathrm{US} \$ 0.69$ or $€ 0.60$.
Finally, to illustrate the difference in profitability between the 2 breeds at a range of fat and protein prices, Equations [1] and [2] were combined to produce Equation [4]:

$$
\begin{aligned}
& \text { Protein }(\mathrm{NZ} \$ / \mathrm{kg})= \\
& \frac{\left\{\begin{array}{l}
\mathrm{F} \$ \times\left[\mathrm{Fkg}_{\mathrm{B} 1}-\mathrm{Fkg}_{\mathrm{B} 2} \times(1+\mathrm{X})\right]+\mathrm{OthInc}_{\mathrm{B} 1} \\
-\left[\mathrm{OthInc}_{\mathrm{B} 2} \times(1+\mathrm{X})\right]-\mathrm{OpEx}_{\mathrm{B} 1}+\left[\mathrm{OpEx}_{\mathrm{B} 2} \times(1+\mathrm{X})\right]
\end{array}\right\}}{\left[\mathrm{Pkg}_{\mathrm{B} 2} \times(1+\mathrm{X})-\mathrm{Pkg}_{\mathrm{B} 1}\right]},
\end{aligned}
$$

where subscripts B1 and B2 denote breeds 1 and 2 . Equations 2 and 4 can be applied only when the profitability of breed 2 is $\geq \mathrm{NZ} \$ 0 /$ ha. Other income (OthInc) and operating expenses (OpEx) were assumed to remain constant, within breed and stocking rate, irrespective of fat and protein price. The breakeven protein price for a given fat price for each breed was calculated by setting Equation 1 (profit) to NZ\$0/ha. As an example of how Equation 4 was used, the protein price for a given fat price, where the profitability of $\mathrm{J}$ was $1 \%$ greater than that of $\mathrm{HF}$, was calculated by setting $\mathrm{X}$ to $1 \%$, using $\mathrm{J}$ values for breed 1 and HF values for breed 2. To illustrate a range of likely scenarios, the actual values for fat and protein for the seasons 2011/12 to 2017/18 paid by a large milk processor (Fonterra Co-operative Group, Auckland, New Zealand), as well as forecast payment at the time of writing for the 2018/19 season, are presented in Figure 1.

The values for fat and protein where the profitability of $\mathrm{J}=\mathrm{NZ} \$ 0 / \mathrm{ha}, \mathrm{HF}=\mathrm{NZ} \$ 0 / \mathrm{ha}$, and $\mathrm{J}=\mathrm{HF}$, and where the profitability of each breed was 0 to $1 \%, 1$ to $5 \%$, and $>5 \%$ greater than the other are presented in Figure 2 for CSR80 (a) and CSR100 (b). Actual fat and protein prices from Figure 1 are also plotted. The results indicate a clear advantage to the $\mathrm{J}$ breed at CSR100, with only a small area of the figure where HF was more profitable, at fat prices less than NZ $\$ 1.00 / \mathrm{kg}$. However, CSR100 is above optimal stocking rate (Macdonald et al., 2011). A lower profitability at CSR100 compared with CSR80, irrespective of breed, was also reported by Spaans et al. (2018); therefore, the remainder of this paper focuses on CSR80.

For CSR80, the profitability of the breeds was equal when fat price was approximately NZ\$5.67 ( \pm NZ\$0.20) per kilogram, depending on protein price (Figure 2a). Protein price had little effect due to the similar production of protein $(\mathrm{kg} / \mathrm{ha})$ between the breeds (Table 1). A fat price of $\mathrm{NZ} \$ 5.67$ ( $\pm \mathrm{NZ} \$ 0.20$ ) per kilogram was the point at which the value of the additional fat produced by $\mathrm{J}$ offset their higher operating expenses. The higher operating expenses of $\mathrm{J}$ explain why they 
are less profitable than HF at lower fat prices (the lefthand side of Figure 2a). When the volume adjustment was excluded, the fat price at which $\mathrm{HF}$ and J achieved equal profitability was NZ $\$ 1.23 / \mathrm{kg}$ higher (at NZ\$6.90/ $\mathrm{kg}$ ). Assuming $40 \%$ of milk is produced in peak months and a peak volume charge of NZ $\$ 0.0132 / \mathrm{L}$, the inclusion of a peak volume adjustment could decrease the fat price at which the breeds are equal by a further $\mathrm{NZ} \$ 0.23 / \mathrm{kg}$ to $\mathrm{NZ} \$ 5.44 / \mathrm{kg} \pm 0.20 / \mathrm{kg}$. This highlights the importance of including all components of the milk price, not only fat and protein, when calculating profitability, especially when there are large differences in milk composition. Furthermore, given that it is not uncommon for famers to select based on breed, followed by genetic merit, these results indicate at which prices (particularly for fat) a farmer might favor $\mathrm{J}$ over $\mathrm{HF}$ (or vice versa) in pasture-based farm systems, assuming similar levels of other income and expenses to those in this study.

Breed selection is a long-term decision. The example actual milk prices (Figure 1) illustrate that protein has generally been of greater value than fat, since 1988 in New Zealand (Hamill, 2018), which has favored the HF breed. In a comprehensive review of the effect of breed on feed conversion efficiency, Grainger and Goddard (2004) reported that the J breed produced more milk solids (fat + protein) per kilogram of DM feed intake than HF did. However, the economic benefit of the extra milk solids was eroded, because the extra milk solids were primarily milk fat and only half as valuable as protein in their economic analysis (Grainger and Goddard, 2004). Recent increases in the price of fat (Global Dairy Trade, 2017) favor the J breed. Furthermore, the value of fat relative to protein will likely continue to increase in coming seasons for processors who calculate milk prices on a rolling average. This change in the value of fat and protein has been reflected in the economic values used in breeding schemes (ICBF, 2017b), resulting in a re-ranking of AI bulls in New Zealand (DairyNZ, 2018c). The average change for bulls by breed group in the New Zealand Breeding Worth index amounted to +NZ $\$ 23$ for J bulls, $-\mathrm{NZ} \$ 28$ for HF bulls, and $-\mathrm{NZ} \$ 4$ for crossbreed $(\mathrm{J} \times \mathrm{HF})$ bulls, which resulted in breed group proportions of $70 \% \mathrm{~J}, 5 \%$ $\mathrm{HF}$, and $25 \%$ crossbreed $(\mathrm{J} \times \mathrm{HF})$ among the top 200 bulls (DairyNZ, 2018c). Previously, these proportions were $50 \% \mathrm{~J}, 15 \% \mathrm{HF}$, and $35 \%$ crossbreed (DairyNZ, 2018d). A limitation of the present analysis is that a)

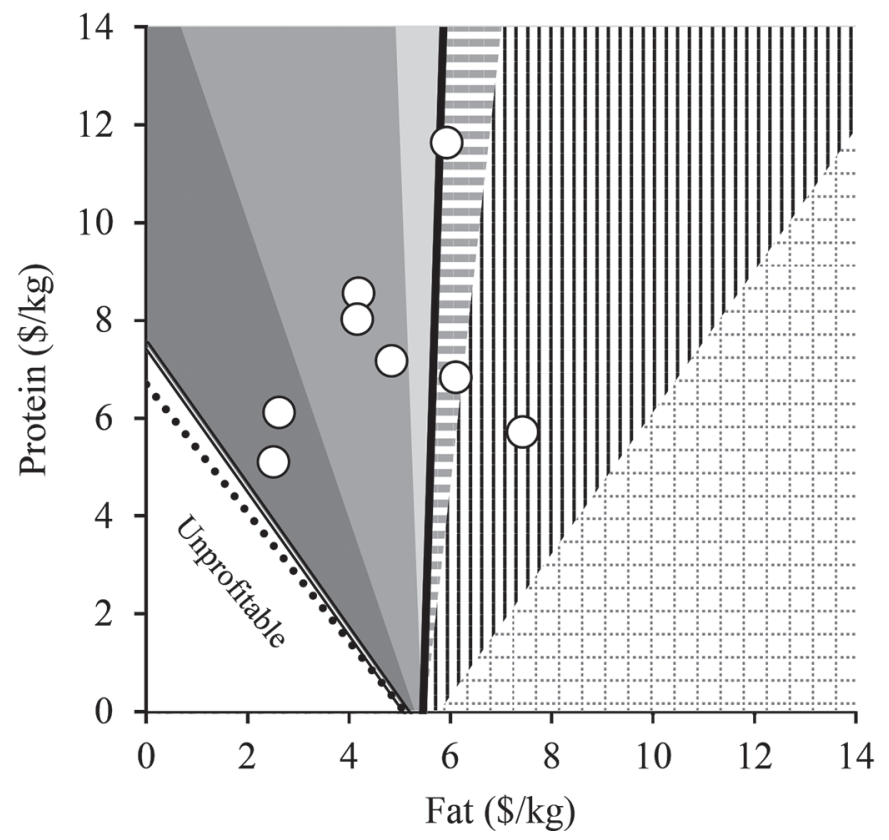

b)

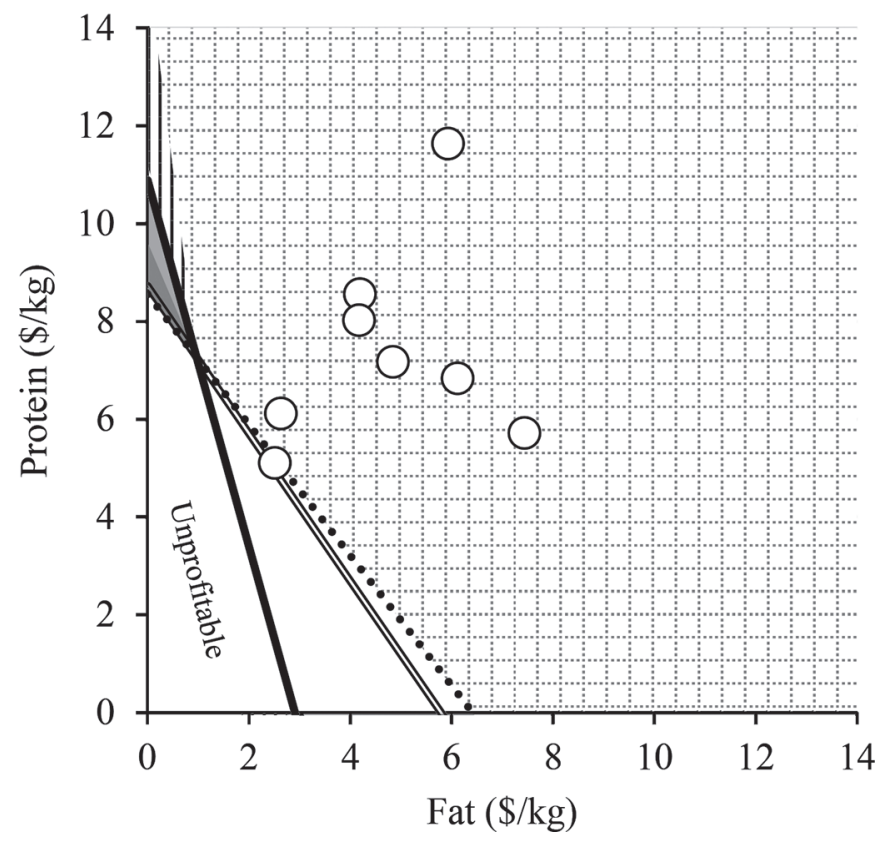

Figure 2. Effects of fat and protein values (NZ\$) on relative profitability of Jersey $(\mathrm{J})$ and Holstein-Friesian (HF) cows at a comparative

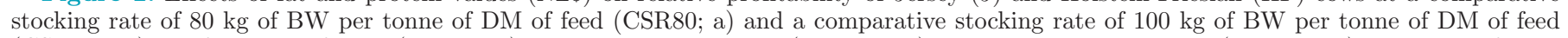
(CSR100; b). Profit J = profit HF (black line); breakeven milk price J (double line); breakeven milk price HF (dotted line); J more profitable

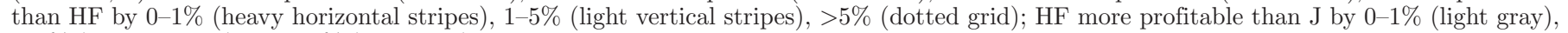

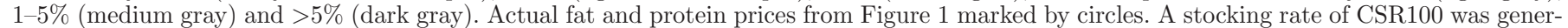

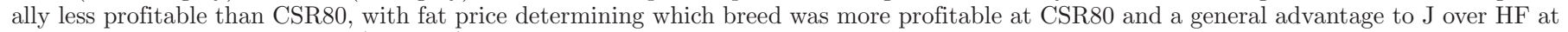
CSR100. At time of writing, NZ\$1 = US\$0.69 or €0.60. 
crossbred animals, which now represent $48 \%$ of cows in New Zealand (DairyNZ, 2018a), were not investigated in the original study by Spaans et al. (2018). A further point to note is that the heterotic advantage farmers experience among crossbred cows is not reflected in the rankings of their purebred sires. Ultimately, farmers should consider the medium- to long-term outlook of fat price in their milk market when evaluating breed choice for their farm system.

\section{ACKNOWLEDGMENTS}

This work was funded by New Zealand Dairy Farmers through DairyNZ Inc.

\section{REFERENCES}

Bailey, K. W., C. M. Jones, and A. J. Heinrichs. 2005. Economic returns to Holstein and Jersey herds under multiple component pricing. J. Dairy Sci. 88:2269-2280. https://doi.org/10.3168/jds .S0022-0302(05)72903-9.

Beecher, M., F. Buckley, S. M. Waters, T. M. Boland, D. EnriquezHidalgo, M. H. Deighton, M. O'Donovan, and E. Lewis. 2014. Gastrointestinal tract size, total-tract digestibility, and rumen microflora in different dairy cow genotypes. J. Dairy Sci. 97:3906-3917. https://doi.org/10.3168/jds.2013-7708.

DairyNZ. 2017. About DairyBase. Accessed Aug. 20, 2018. https:// www.dairynz.co.nz/business/dairybase/about-dairybase/.

DairyNZ. 2018a. New Zealand dairy statistics 2017-18. Accessed Nov. 27, 2018. https://www.dairynz.co.nz/media/5790451/nz-dairy -statistics-2017-18.pdf.

DairyNZ. 2018b. The 5 production systems. Accessed Aug. 20, 2018. https://www.dairynz.co.nz/business/the-5-production-systems/.

DairyNZ. 2018c. Bull breeding worth shifts reflect increase in value of fat. Accessed Sep. 30, 2018. https://www.dairynz.co.nz/news/ latest-news/bull-breeding-worth-shifts-reflect-increase-in-value-of -fat/.

DairyNZ. 2018d. BW Bull File. Accessed Mar. 23, 2018. www.dairynz .co.nz/media/5790003/bw-bull-file_2018august13.csv.
Elbehri, A., R. D. Yonkers, S. A. Ford, and S. I. Gripp. 1994. The relative profitability of Jersey versus Holstein farms under alternative milk pricing systems. J. Dairy Sci. 77:1296-1305. https://doi.org/ 10.3168/jds.S0022-0302(94)77069-7.

Global Dairy Trade. 2017. Annual Report 2017. Accessed Dec. 12 2018. https://www.globaldairytrade.info/assets/Uploads/ resources/Annual-Report-2017.pdf?v=17584.

Grainger, C., and M. E. Goddard. 2004. A review of the effects of dairy breed on feed conversion efficiency-An opportunity lost? Pages 77-80 in Proc. 25th Biennial Conference of the Australian Society of Animal Production, Vol. 25. University of Melbourne, Victoria, Australia. CSIRO Publishing, Clayton, Australia.

Hamill, G. 2018. Milksolid matters: Fat-to-protein values get close to parity. Accessed Nov. 4, 2018. https://www.lic.co.nz/news/ milksolid-matters-fat-protein-values-get-close-parity/.

ICBF (Irish Cattle Breeding Federation). 2017a. Beef and Dairy Breed Statistics 2017. Irish Cattle Breeding Federation Society Limited, Bandon, Co. Cork, Ireland. Accessed Nov. 4, 2018. https://issuu .com/herdplus/docs/beef__dairy_breed_stats_2017.

ICBF (Irish Cattle Breeding Federation). 2017b. Update to Economic Values in the EBI. Accessed Nov. 4, 2018. https://www.icbf.com/ $\mathrm{wp} / \mathrm{p}=9695$.

L'Huillier, P. J., C. R. Parr, and A. M. Bryant. 1988. Comparative performance and energy metabolism of Jerseys and Friesians in early-mid lactation. Proc. N.Z. Soc. Anim. Prod. 48:231-236. http: //www.nzsap.org/system/files/proceedings/1988/ab88046.pdf.

Macdonald, K. A., D. Beca, J. W. Penno, J. A. S. Lancaster, and J. R. Roche. 2011. Short communication: Effect of stocking rate on the economics of pasture-based dairy farms. J. Dairy Sci. 94:25812586. https://doi.org/10.3168/jds.2010-3688.

Prendiville, R., K. M. Pierce, and F. Buckley. 2009. An evaluation of production efficiencies among lactating Holstein-Friesian, Jersey, and Jersey $\times$ Holstein-Friesian cows at pasture. J. Dairy Sci. 92:6176-6185. https://doi.org/10.3168/jds.2009-2292.

Schmidt, G. H., and D. E. Pritchard. 1988. Effect of milk pricing systems on income over feed and variable costs of dairy cattle breeds. J. Dairy Sci. 71:1097-1103. https://doi.org/10.3168/jds .S0022-0302(88)79658-7.

Spaans, O. K., K. A. Macdonald, J. A. S. Lancaster, A. M. Bryant, and J. R. Roche. 2018. Dairy cow breed interacts with stocking rate in temperate pasture-based dairy production systems. J. Dairy Sci. 101:4690-4702. https://doi.org/10.3168/jds.2017-14032. 